\title{
The measurement of successfully completed projects funded by the European Union
}

\author{
Laura Siposné Sinóros-Szabó \\ EU Development Officer, Ministry of Human Resources, Hungary, Budapest \\ laura.sinoros-szabo@emmi.gov.hu
}

SUMMARY

Projects funded by the European Union contribute significantly to the socio-economic development of Hungary, its increasing competitiveness, thereby the local people's general level of satisfaction, their "happiness and prosperity". Successful spending from the Union's funds, successful project implementation directly impacts all actors in the Hungarian economy and society. Therefore, to examine the factors that support or jeopardize the implementation of the projects is a priority at EU and national levels. My research and doctoral dissertation aims to develop a methodology to assess the management efficiency of projects supported by the European Union, implemented in Hungary taking into account all measurable factors (technical and special expertise) and the "suspected" factor (EU thinking learning). I intend to draw up guidelines for future EU funded project management teams to realize projects successfully for the benefit of Hungary.

Keywords: EU funds, tendering, management efficiency measurement

\section{ÖSSZEFOGLALÁS}

Az Európai Unió támogatásával megvalósuló projektek jelentősen hozzájárulnak Magyarország társadalmi-gazdasági fejlödéséhez, növekvö versenyképességéhez, ezáltal a lakosság általános megelégedettségéhez, "boldogságához és jólétéhez”. Az Uniós támogatások sikeres elköltése, a sikeres projektmegvalósitás közvetlen hatást gyakorol a magyar gazdaság és társadalom minden szereplöjére. Következésképpen, annak megvizsgálása, hogy mely tényezök támogatják vagy gátolják a projektek megvalósitását elsödleges fontosságú uniós és nemzeti szinten. Kutatásaim és doktori disszertációm célja módszertan kidolgozása az európai uniós támogatású, Magyarországon megvalósuló projektek menedzsmentjének a hatékonyságmérésére, figyelembe véve valamennyi mérhetö (müszaki és speciális szaktudás) és ,"feltételezhetö” (EU gondolkodás elsajátítása) tényezöt. Szándékom, hogy a jövöbeli Európai Unió által finanszirrozott projektek menedzsment csapatai számára irányelveket dolgozzak ki a projektek sikeres megvalósitása érdekében Magyarország javára.

Kulcsszavak: európai uniós támogatások, pályázás, menedzsment hatékonyság mérés

\section{INTRODUCTION}

Hungary's accession to the EU raised a number of institutional, operational, procedural and sovereignty issues. By today most of these questions have got answered or are being examined for further consideration. The most important question probably has always been "How much money Hungary will get?" It is answered by the European Union's regional and structural policy.

The European Union set the objective of creating economic and social cohesion among the member countries, the minimization of differences between the levels of development, which ensures the well-being of EU citizens, downwarding pressure on "unemployment to negligible levels, uniformly developed regions, rural areas, wages and salaries catching up, and uniform - EU average - pensions" (Flamm and Nagy, 2003).

The objectives of the EU regional and structural policy are achieved through the support and funding of improvements. The EU provides multi-billion Euros per year support for the member countries' development programs and projects via the Structural Funds and the Cohesion Fund. Grants for development programs can be obtained through tenders. Hungary has the most resources come through the Structural Funds, which aim to support infrastructure investments in underdeveloped regions and economic competitiveness-enhancing measures. The condition for obtaining the resources is that the member country's GDP does not reach $75 \%$ of the EU average (in terms of purchasing power parity). Of the Structural Funds the European Regional Development
Fund (ERDF) and European Social Fund support the following objectives:

1. support for the development of underdeveloped areas and for structural adjustment,

2. supporting economic and social conversion of regions facing structural difficulties,

3. development of human resource management, reducing long-term unemployment, modernization of education, training and employment systems and policies (ESF).

One of the most important prerequisites of the inclusion of the funding from the Structural Funds is using the NUTS (Nomenclature des Unites Territoriales Statustiques) classification system. Initially NUTS had five degrees based on regional and statistical data, currently three levels are defined. In Hungary, NUTS level 1 consists of the parts of the country: Transdanubia, Central Hungary and the Great Plains and the North. The NUTS level 2 corresponds to the statistical regions, while at the NUTS 3 level the county system is situated. In Hungary 7 NUTS II level regions were assigned in 1998, which are:

- Western Transdanubia,

- Central Transdanubia,

- Southern Transdanubia,

- Central Hungary Region,

- Northern Hungary,

- Northern Plains Region,

- South Plains Region (Figure 1).

The classification entitles our country to the use of EU funds. However, receiving the money has strict financial, administrative and organizational regulations. 


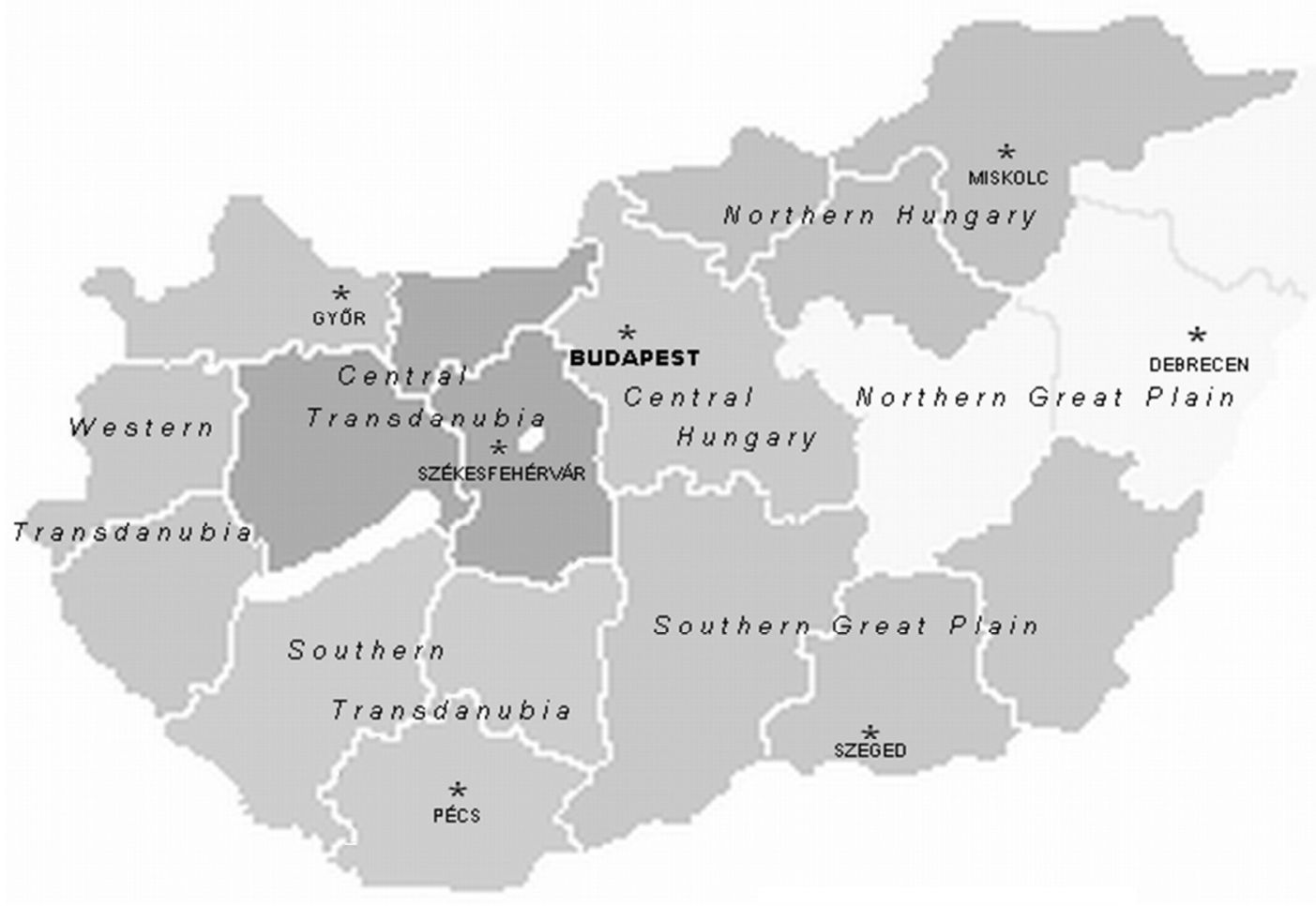

Source: Net1

\section{DOMESTIC USE OF EU SUBSIDIES}

EU Member States should prepare national development plans providing information on the purposes and area a particular Member State uses the funds granted. Another purpose of the National Development Plan is drawing up a comprehensive national strategy based on the country's resources. The National Development Plans include operational programs that define the areas of development and the detailed regulation of the use of resources funded from the grant. Hungary's first National Development Plan (NDP I) covered the period from 2004 to 2006 and contained five operational programs. Our country's second National Development Plan is called the New Hungary Development Plan and regulated the use of EU support in the period 2007-2013 in 15 Operative Programs (the regional operational programs were included in it separately) (Net2). The distribution of EU funds to be used in the period 2014-2020 is controlled by Széchenyi 2020 program and is aligned with the Europe Union's 11 thematic objectives. The scale of EU funding depends on the severity of the problem to be supported, the financial capacity of the Member States, the importance of the support from regional and EU perspective and the specific characteristics of the activity (Flamm and Nagy, 2003) (Figure 2).

\section{TENDERING}

EU funds can be obtained through tenders, of which one of the conditions is being consistent with the European Union's policies and objectives. Besides, the ways and means of how to win the tender should also be recognized. In addition to technical knowledge (preparation of project proposal) and specific knowledge (EU legislation, goals, etc.) you need less specific, but important skills: acquiring the European Union thinking.

In the preparation of EU projects it is required to display the following principles, of which knowledge is essential for every person contributing to project realization:

- partnership (securing the widest possible socioeconomic participation in the project),

- programming (the implementation of the regulatory process of EU support compliance goals),

- additionality (refers to the complementary nature of subsidies),

- co-financing (own funds),

- concentration (grants may be used for limited purposes),

- compatibility (ensuring the consistency of the Union's and the Funds' objectives).

Compliance with the rules listed in the tender can be measured already in the preparatory phase of the project, at application writing and planning.

The available budget for the next programming period was decided in December 2013. In 2014-2020, Hungary will manage ten operational programs within the EU financial framework. 60 percent of the funds will be directed as planned for three operative programs aimed at economic development. These include the economic development and innovation program, the regional development program and the Central Hungary competitiveness program. 
Figure 2: Allocation of cohesion policy funds for the programming period 2014-2020 (million EUR)

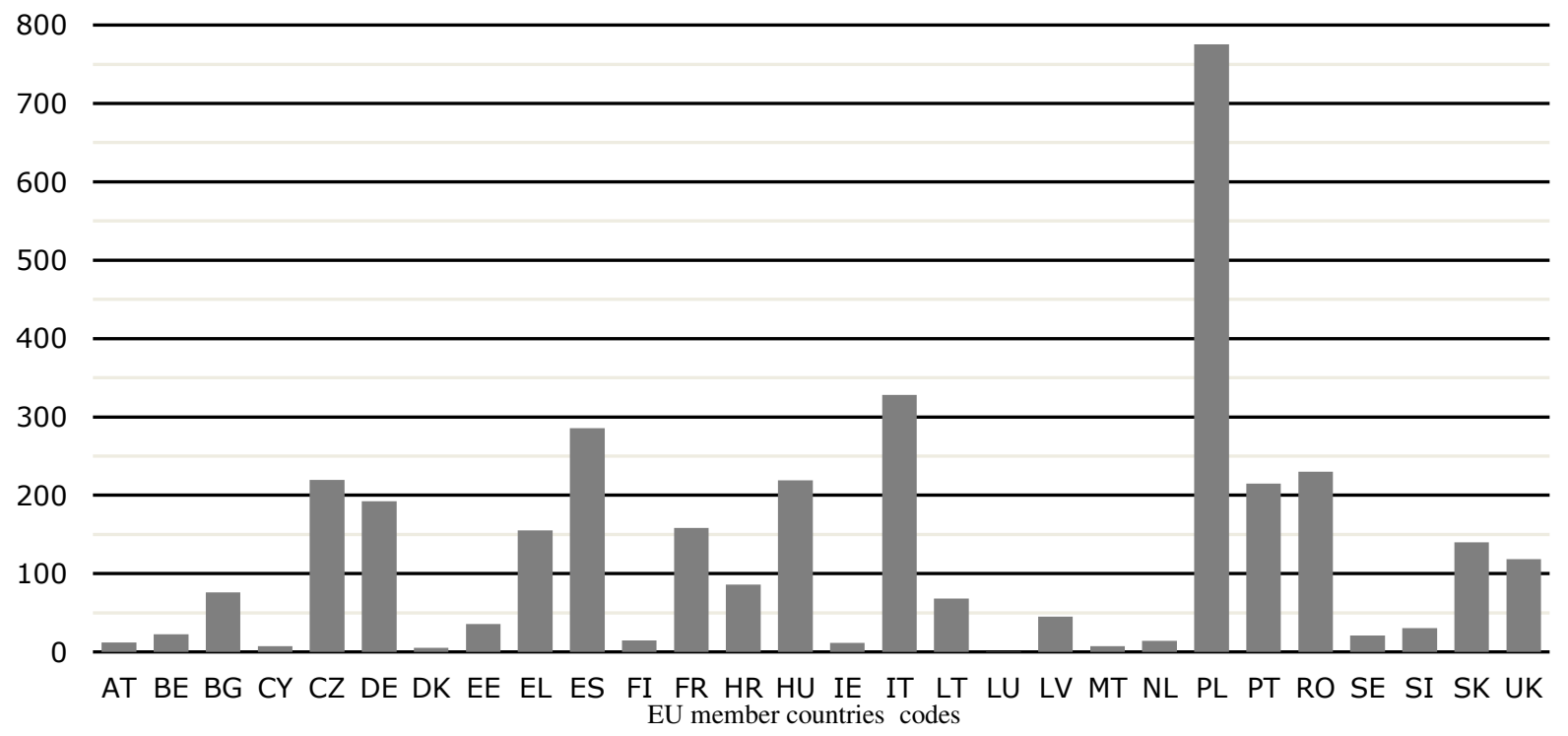

Source: Net3

For 2014-2020, Hungary has been allocated $€ 21.9$ billion (current prices) in total Cohesion Policy funding:

- $€ 15$ billion for less developed regions (GDP/head $<75 \%$ of EU average) (Central Transdanubia, Western Transdanubia, Southern Transdanubia, Northern Hungary, Northern Plains Region and Southern Plains Region);

- $€ 463.7$ million for the more developed region (Central Hungary);

- $€ 6$ billion under the Cohesion Fund;

- $€ 361.8$ million for European Territorial Cooperation;

- $€ 49.8$ million for the Youth Employment Initiative.

Of this, the ESF will represent $€ 4.7$ billion, $30.46 \%$ of the Structural Funds resources (Net2).

\section{MEASURING PROJECT MANAGEMENT BY DATA ENVELOPMENT ANALYSIS METHOD}

If Hungary spends 2014-2020 EU funds successfully, meaning it manages to realize the most possible projects within time and budget, it should lead to a faster convergence. It is estimated that by a satisfying absorption level in the Central Eastern European countries (including Hungary) the differences in stage of development should steadily diminish (Jedlička and Rzentarzewska, 2014). To achieve a satisfying level of absorption, projects need efficient management teams and management efficiency should be measured in order to determine guidelines and methods to be followed.

Project management efficiency could be measured by Data Envelopment Analysis (DEA) (Somogyi, 2007). DEA is a performance measurement technique that is used for evaluating relative efficiency of the same or similar decision making units having some degree of discretion (but not necessarily full) and they could be categorized as efficient or non-efficient. These units use inputs to form outputs. DEA has already been used to measure among others banks, police stations, hospitals, prisons, schools, university departments, department stores, regional agencies and advertising agencies. The method was discovered by Charnes, Cooper and Rhodes in 1978 and since then it has been the subject of several theoretical research and practical application.

In my research I wish to establish a measurement system to assess European Union subsidized project management efficiency in Hungary. It is possible to use various input and output categories, which may have completely different unit of measurement. The advantage of the method is that input and output categories can be determined by the researcher. I suggest the following inputs and outputs to be measured (the list is not final).

Possible inputs can be:

- number of hours worked per day,

- number of days worked per project,

- number of days spent on different project phase: preparation, realization and closing respectively,

- number of project team members.

Possible outputs can be:

- indicators (project commitments) completed,

- the rate of budget spending,

- the number of EU policies/objectives involved in the project,

- the number of deadline extensions.

\section{RECOMMENDATIONS}

In my research I intend to determine input and output categories to measure EU funded project management efficiency in Hungary. Based on the categories interviews, tests and reports will be prepared. The results will be used to define efficiency and draw up guidelines for future EU funded project management teams to realize projects successfully for the benefit of Hungary. 


\section{REFERENCES}

Flamm B. L.-Nagy S. Gy. (szerk.) (2003): Belépődíj - A magyar EU-csatlakozás kérdései és válaszai. Európai Unió Munkacsoport közhasznú Diákegyesület. Budapest.

Jedlička, J.- Rzentarzewska, K. (2014): Cohesion Policy and other EU assistance programmes in 2014-2020. Česká spořitelna EU Office. Pague.

Net1: Regions Hungary. Licensed under Creative Commons AttributionShare Alike 3.0 via Wikimedia Commons. http://commons. wikimedia.org/wiki/File:RegionsHungary.png\#mediaviewer/ File:RegionsHungary.png
Net2: Területi tervezés. www.külker.hu/wp-content/uploads/2013/ 03/Területi-tervezés-05.05.ppt

Net3: http://ec.europa.eu/regional_policy/information/cohesionpolicy-achievement-and-future-investment/factsheet/hungary_ en.pdf

Somogyi Cs. A. (2007): Data Envelopment Analysis módszertan alkalmazási lehetőségei a 2007-2013-as időszaki NSRK-támogatási intézményrendszere hatékonyságának vizsgálatában. Nemzeti Fejlesztési Ügynökség. Módszertani füzetek. 